\title{
Sectional Evaluation of Anatomic Structures in Cat (Felis catus) Thoracic Cavity by Computed Tomography Imaging and Silicone Plastination Methods
}

\author{
Evaluación Seccional de Estructuras Anatómicas de la Cavidad Torácica en Gato \\ (Felis catus) con Imágenes de Tomografía Computada y Métodos de Plastinación de Silicona
}

\author{
Remzi Orkun Akgün; Caner Bakici; Okan Ekim; Ali Bumin \& Ismail Önder Orhan
}

AKGÜN, R. O.; BAKICI, C.; EKIM, O.; BUMIN, A. \& ÖNDER, O. I. Sectional evaluation of anatomic structures in cat (Felis catus) thoracic cavity by computed tomography maging and silicone plastination methods. Int. J. Morphol., 36(4):1246-1251, 2018.

SUMMARY: It was aimed to determine the anatomical structures in thoracic cavity by computed tomography imaging (CT) and compare the cross sectional images in the same specimens which were plastinated after CT imaging. It was also aimed to obtain 3 dimensional (3D) reconstructions of thoracic anatomical structures. Thoracic organs of 3 adult cats were CT imaged and then plastinated in this study. Specimens were plastinated in the same body position in the CT imaging process. CT images and corresponding plastinated cross sections were compared to each other. Anatomical structures of the thoracic cavity in plastinates were in accordance with CT images. Beside the bony structures, other organs such as esophagus, trachea, heart with related vessels, lungs and thoracic muscles were well defined in CT images and plastinates. Moreover, 3D reconstructed images of anatomical structures of thoracic cavity were acquired well. This study is thought to be beneficial for veterinary surgery and radiology fields as well as veterinary anatomy educations.

KEY WORDS: Cat; Computed tomography; Silicone; Plastination; Thorax anatomy; Three-dimensional.

\section{INTRODUCTION}

In addition to the continued popularity of cats as pets all over the world, there has been a considerable increase in the cat population in Turkey in recent years. Depending upon that, clinical approaches for cat medicine have gained importance. There has also been a steady increase in veterinary use of modern radio-diagnostic techniques such as computed tomography (CT), ultrasound (US) and magnetic resonance imaging (MRI) in last decade. CT is an imaging technique based on X-ray technology (Estai \& Bunt, 2016). Although CT has been used in human medicine since the early 1970 s, it has taken place in veterinary medicine only towards the end of the 1990s (Brenner \& Hall, 2007). Most of the anatomical or pathological structures in the body cavities can be easily identified with this method (Labruyere $\&$ Schwarz, 2013). The main diseases of the feline thoracic cavity that veterinarians encounter can be mostly diagnosed by CT technique. There have been many studies focused on the diagnosis of thoracic diseases of cats (Henninger, 2003; Ohlerth \& Scharf, 2007; Rose et al., 2017). However, in order to detect the thoracic pathological alterations accurately in $\mathrm{CT}$, the healthy macro-anatomical structure of this body region to be imaged should be well known (Samii et al., 1998). Starting from this point of view, previous studies indicating cross sectional anatomical structures and CT images of thoracic cavity of cats were evaluated in detailed manner (Samii et al.; Shojaei et al., 2003). Scientists frequently refer to the plastination method, which has a unique place among the methods of preparing and preserving anatomical specimens (Kumro et al., 2013; von Hagens et al., 1987). Plastination is an anatomical technique to preserve biological specimens for various purposes (Riederer, 2014). This technique was first introduced by Professor Gunther von Hagens at the University of Heidelberg in Germany (Polgar et al., 2003). Silicone plastination is characterized embeeding of silicone polymer instead of tissue fluids in the specimens (DeJong \& Henry, 2007).

For many years trainers have aimed to improve teaching methods by using electronic applications in medical curriculum. Especially medical trainers in the field of human anatomy have turned to 3D computer models as an alternative educational tool (Chang et al., 2016; Estai \& Bunt). 3D 
models help the students to understand the complex topographic and functional relationships simply and accurately (Brazina et al., 2014). This reconstructed anatomical models is expected to be efficient for veterinary education as well as human medicine (Böttcher \& Maierl, 1999). Moreover, 3D reconstructed models or digital images can be convenient for pre-operative surgical plannings and simulations (Kim et al., 2012). In general, CT and MR imaging techniques produce a series of $2 \mathrm{D}$ images. These images are digitally stored in the international standard Digital Imaging and Communications in Medicine (DICOM) file format and can be run with different medical systems at any extra cost for data conversion. 3D models can be produced with spesified softwares through the reconstruction of DICOM files obtained by various imaging techniques. These improved softwares allow the anatomical structure of the examined region to be clearly demonstrated, measured or highlighted (Özkadif, 2015).

In this study, it was aimed to determine the healthy anatomical structures in thoracic cavity of the cat by CT imaging method and then compare the images with the corresponding plastinated cross sections of the same individuals. It was also aimed to obtain $3 \mathrm{D}$ reconstructed models of certain thoracic anatomical structures using CT images.

\section{MATERIAL AND METHOD}

Three adult domestic cats, died from various causes that didn't affect the thoracic organs, were imaged and then plastinated in this study. This study was confirmed by Ankara University Animal Experiments Local Ethics Committee (Decision no: 2017-13-109). CT imaging was performed with a single detector spiral CT scanner device (General Electric, GE Medical Systems, Milwaukee, WI brand, 2119734-2 model) in which the cats were placed in prone position (Fig. 1a). CT scanning was performed in $1 \mathrm{~mm}$ thickness from cranial to caudal direction, between the entrance and exit of thoracic cavity. Technical CT imaging parameters were as follows: $120 \mathrm{kV}, 190 \mathrm{~mA}$, slice increment of $0.5 \mathrm{~mm}$, window setting (for bony tissue; WW: $1000 \mathrm{HU}$, WL: $400 \mathrm{HU} /$ for soft tissue; WW: $1400 \mathrm{HU}, \mathrm{WL}$ : -500 HU) and matrix size of 512 X 512.

Two dimensional DICOM files were uploaded to 3D Slicer Software (3D slicer, 4.7.0 version, GitHub, San Francisco) for 3D reconstruction. In 3D modeling, segmentation and volume rendering were performed from transversal, frontal and sagittal CT sections. After the CT imaging and 3D reconstruction were completed, silicone plastination method was carried out for thoracic cavity of same individulas. In silicone plastination; $4 \%$ formalin fixation, dehydration (Fig. 1b), defatting, forced impregnation (Fig. 1c, d) and gas curing (Fig. 1e, g) stages were performed, respectively. Pure (99.5 $\%$ ) acetone (BirpaKimya, Ankara / Turkey) was used during the dehydration stage. Three consecutive acetone baths were carried out in series at $-25^{\circ} \mathrm{C}$. After the dehydration process
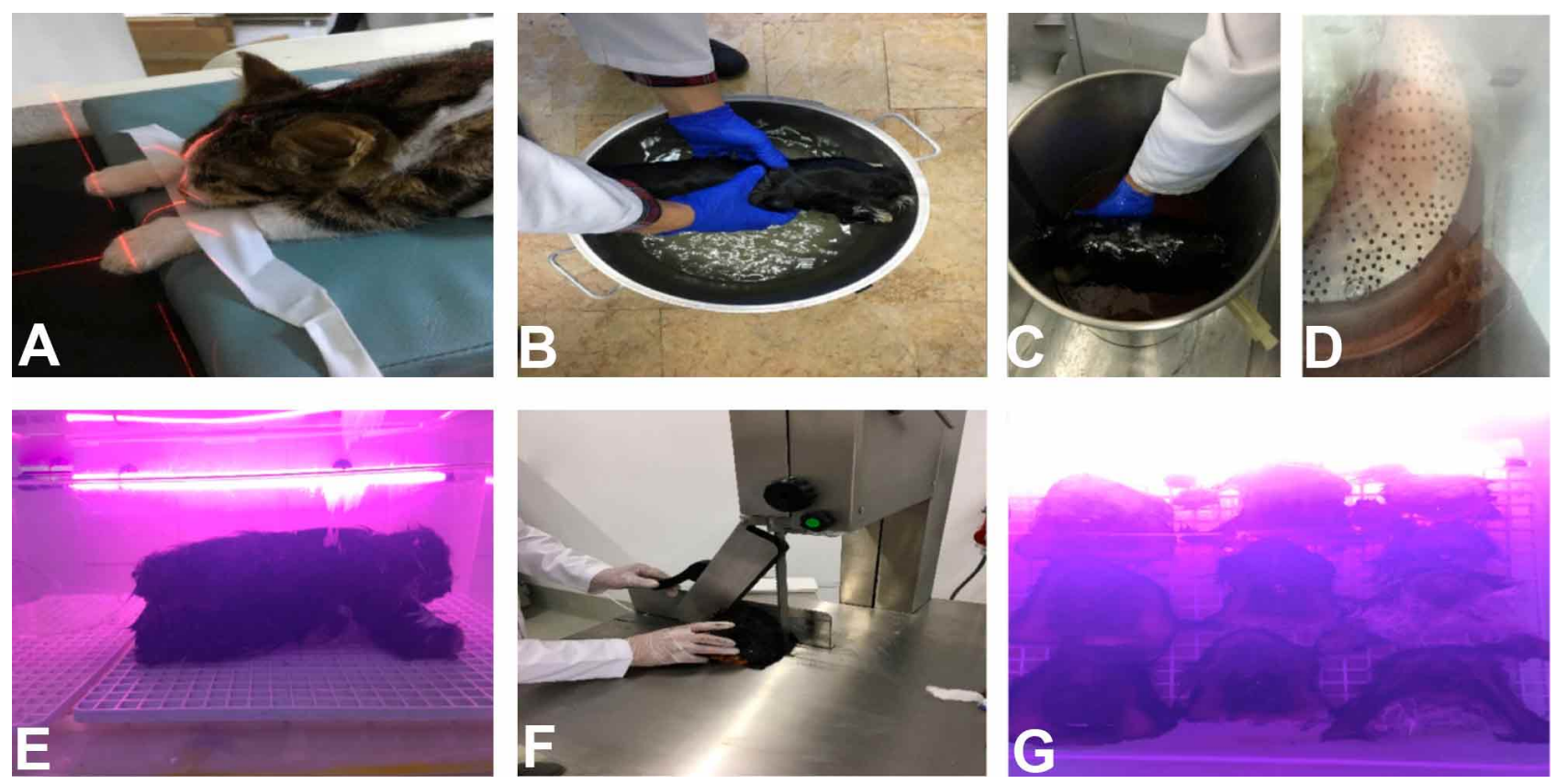

Fig. 1. CT imaging and silicone plastination stages of cats; A position of the cat on the CT device, B dehydration stage, C-D forced impgregnation stage, E gas curing stage, F slicing of sample with an electric bandsaw, G re-hardening of sections 
was completed, cold temperature forced impregnation was carried out at $-25^{\circ} \mathrm{C}$ and under a negative pressure. Basically S10B silicone polymer (Biodur Products, Heidelberg / Germany) and S3 catalyst material (Biodur Products, Heidelberg / Germany) were used for impregnation. After the forced impregnation step was completed, the silicone polymer drawn into the samples was allowed to cure using S6 chemistry (Biodur Products, Heidelberg / Germany). Afterwards, plastinated specimens were cut into $1 \mathrm{~cm}$ thick transversal slices with an electric bandsaw (Electric Band Saw, Mutas, Turkey) (Fig. 1f). Transversal cross-sections of the thoracic cavity consonant to CT images were identified and photographed. CT and plastinated images were compared to each other and anatomical structures were indicated.

\section{RESULTS}

Beside the bony structures, other organs such as esophagus, trachea, heart with related vessels, lungs and thoracic muscles were well defined in CT images and in plastinated sections either. It was seen that transversal sections of plastinated specimens were in accordance with the CT images in same levels (Fig. 2, 3, 4). The shrinkage effect was very limited in bony structures and therefore no prominent alterations were detected in outer thoracic cavity dimensions of plastinates. However, a considerable shrinkage was noticed in the cardiac muscles and lungs. In 3D reconstruction stage, whole bony structures of thoracic cavity, heart with some related vessels, esophagus, lungs, trachea were easily modeled (Fig. 5, 6).
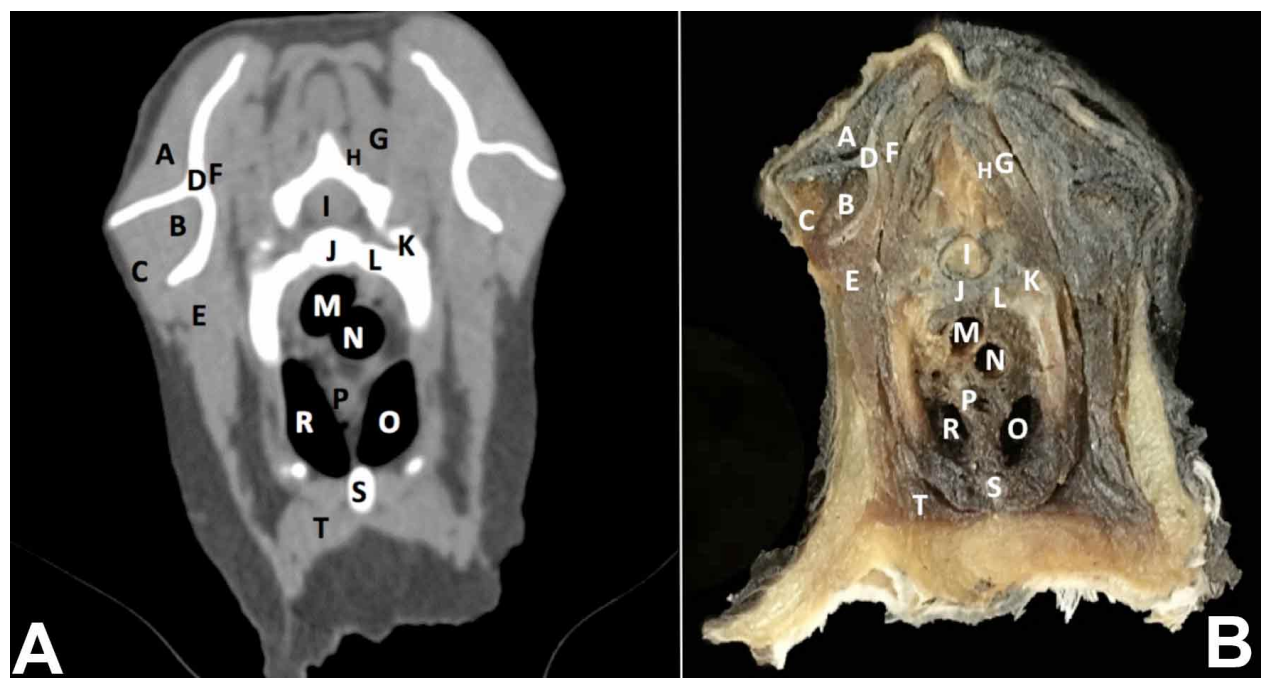

Fig. 2. Transversal CT A. and plastinated section B. images of the cranial part of the thoracic cavity. A; supraspinatus m. B; infraspinatus $\mathrm{m}$. $\mathrm{C}$; deltoideus $\mathrm{m}$. $\mathrm{D}$; scapula E; triceps brachii $\mathrm{m}$. F; subscapularis m. G; longissimus thoracis m. $\mathrm{H}$; spinalis et semispinalis thoracis m. I; spinal cord $\mathrm{J}$; thoracic vertebra $\mathrm{K}$; tuberculum costae $\mathrm{L}$; caput costae $\mathrm{M}$; esophagus $\mathrm{N}$; trachea $\mathrm{O}$; right lung $\mathrm{P}$; cranial vena cava $R$; left lung $S$; manubrium $\mathrm{T}$; pectoralis $\mathrm{mm}$.
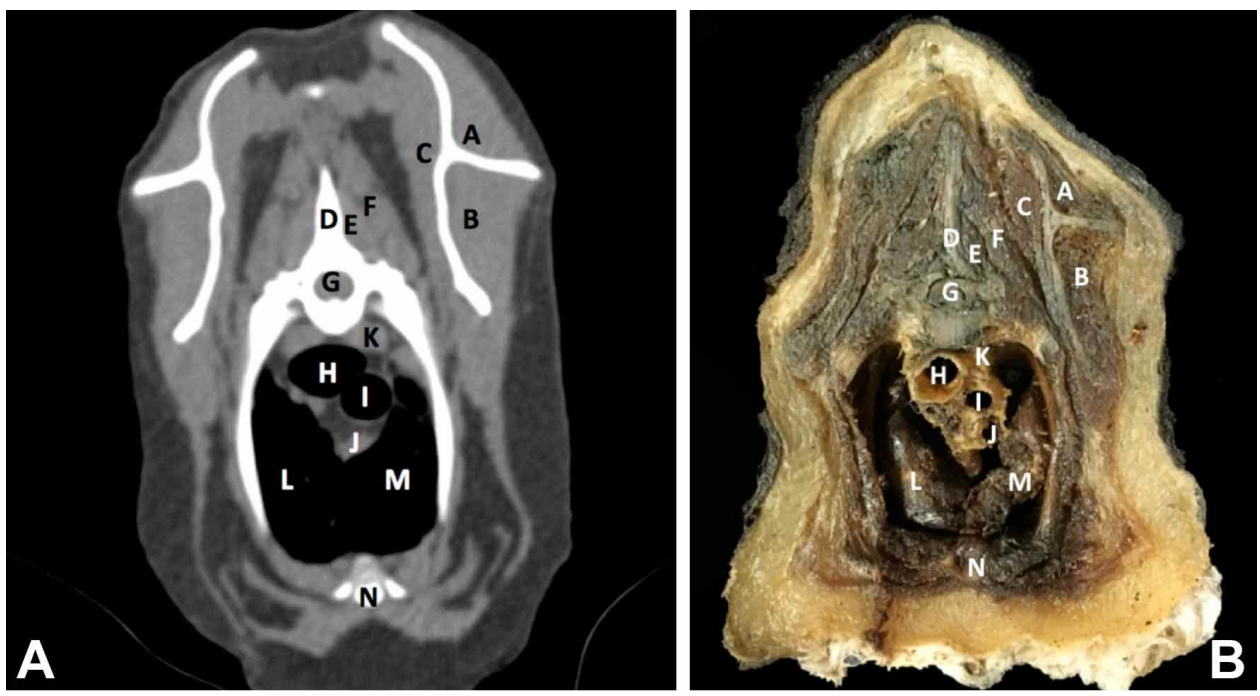

Fig. 3. Transversal CT A. and plastinated section $\mathrm{B}$. images of the medial part of the thoracic cavity. A; supraspinatus m. B; infraspinatus m. C; subscapularis $\mathrm{m}$. D; spinous process $\mathrm{E}$; spinalis et semispinalis thoracis $\mathrm{m}$. F; longissimus thoracis $\mathrm{m}$. G; spinal cord $\mathrm{H}$; esophagus I; trachea J; brachiocephalic trunk K; longus colli m. L; left lung M; right lung $\mathrm{N}$; sternebra 


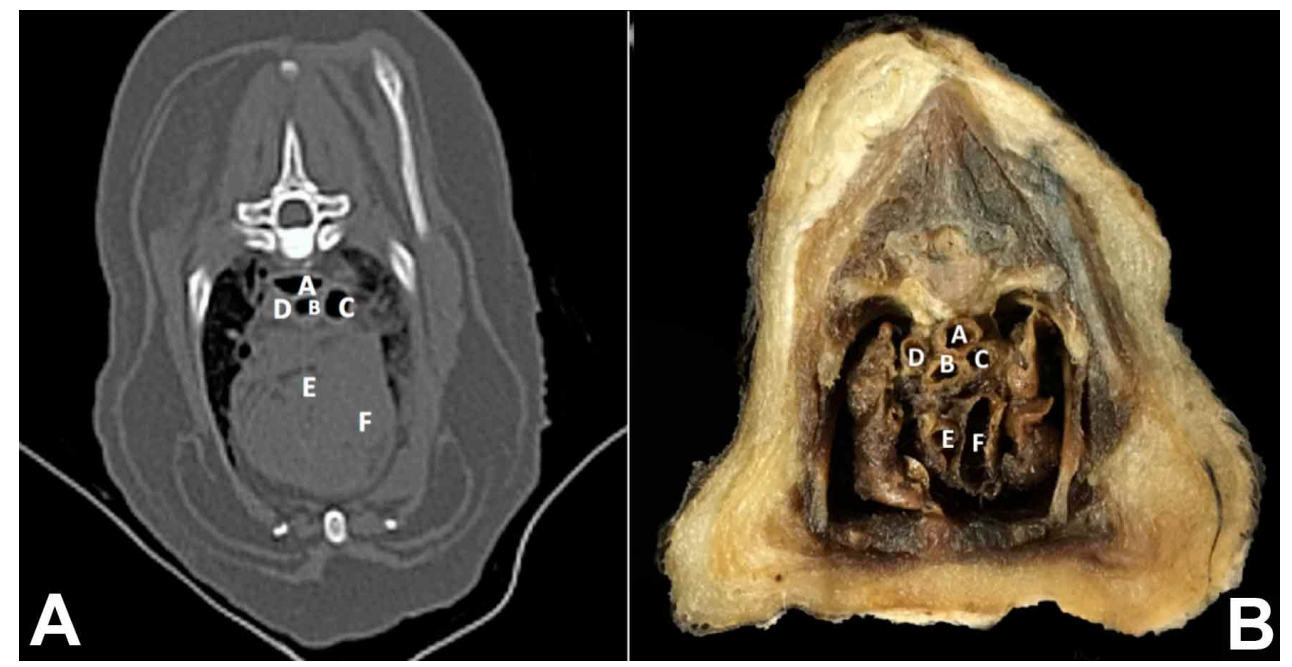

Fig. 4. Transversal CT A and plastinated section $\mathrm{B}$ images of the caudal part of the thoracic cavity. A; esophagus. B; left bronchus $\mathrm{C}$; right bronchus $\mathrm{D}$; descending aorta $\mathrm{E}$; ascending aorta $\mathrm{F}$; right ventricle.
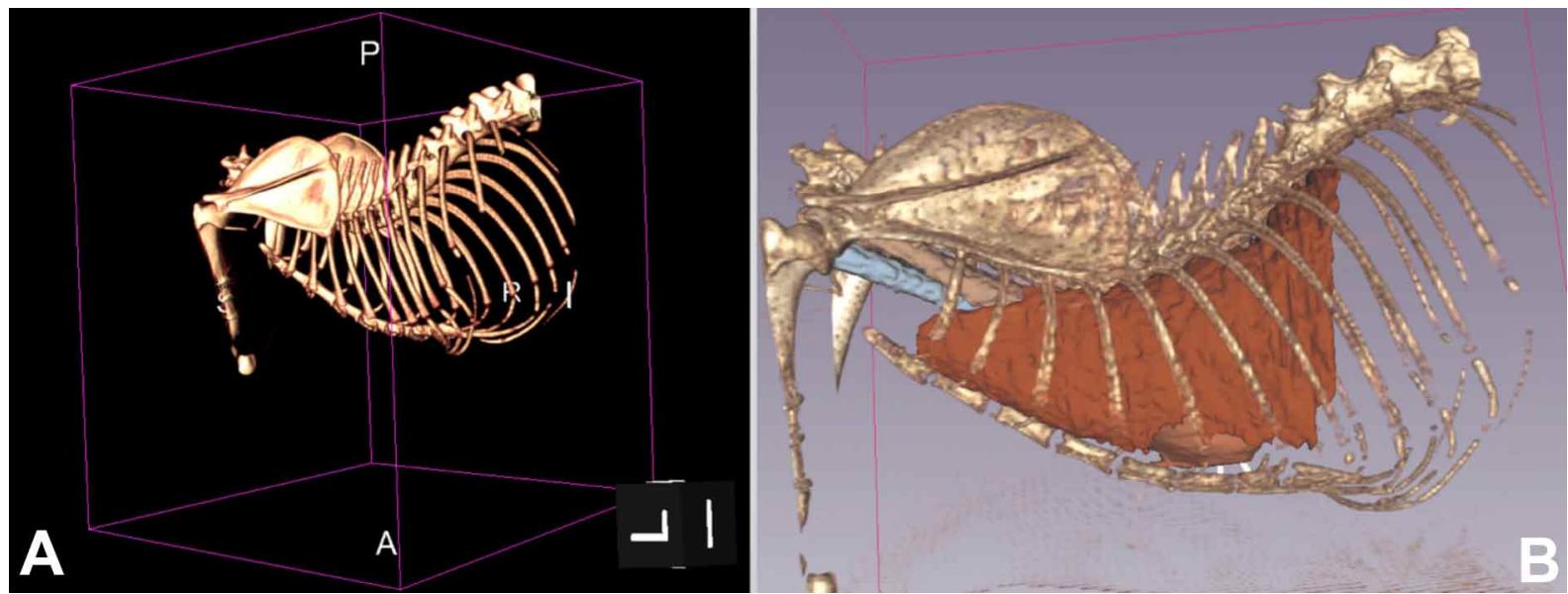

Fig. 5. Laterocaudal view of 3D model of skeleton thoracic A. and lateral view of 3D model of thoracic cavity with internal organs (esophagus, trachea, left lung and heart)B.
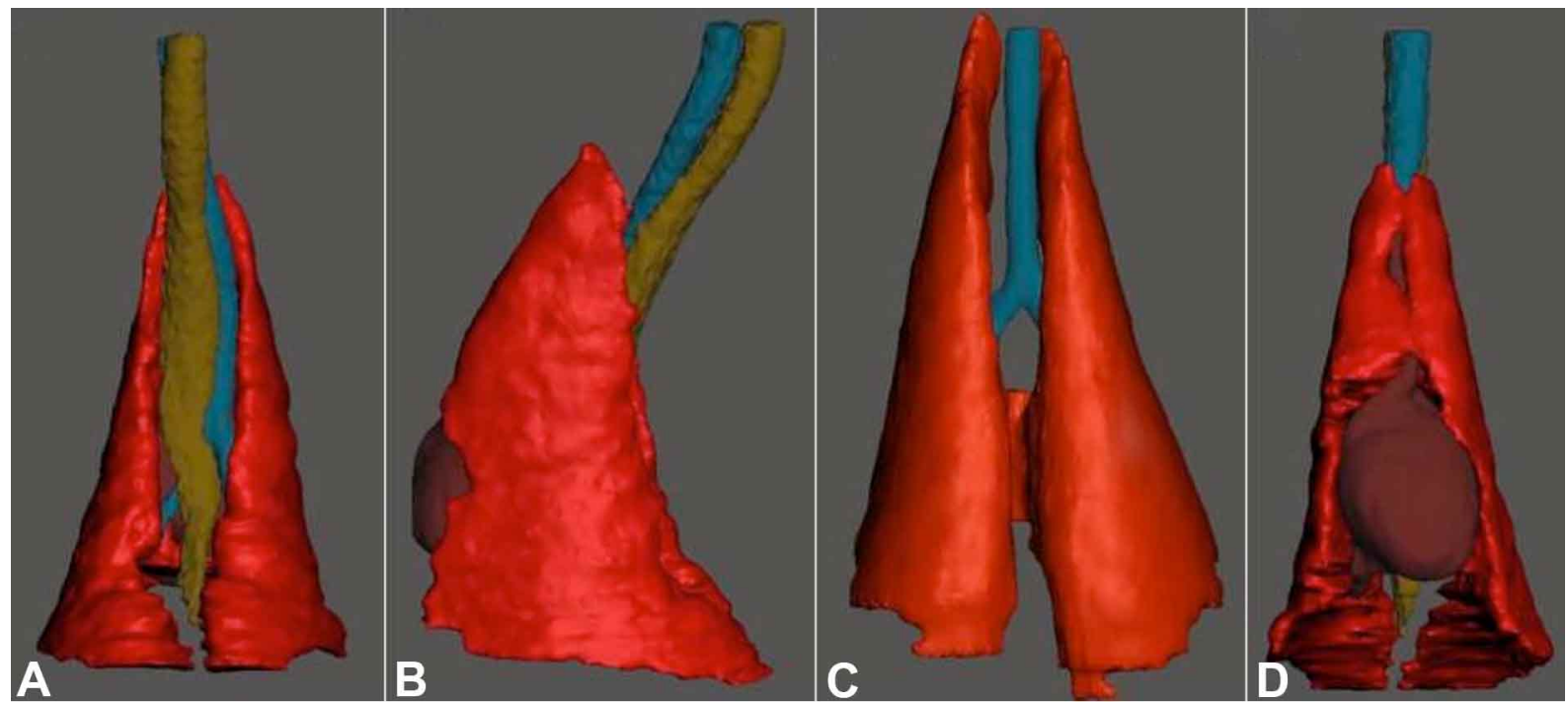

Fig. 6. 3D reconstruction images of the internal organs of the thoracic cavity; A. Dorsal view (lungs, esophagus, trachea), B Lateral view (left lung, esophagus, trachea, heart), C. Dorsal view (trachea, left and right branches, lungs), D. Ventral view (heart, cranial vena cava, trachea, lungs). 


\section{DISCUSSION}

It has been stated that the anatomic specimens prepared by plastination method are elastic, durable, odorless and non-hazardous (Kumro et al.). The cross-sectional plastinates obtained in our study were also extremely durable and harmless to human health. It has been indicated that one of the greatest advantages of plastination method is to cause minimal alterations in the topography of the body structures to be examined and therefore it could be compared with images that are obtained by medical imaging methods such as MRI and CT (Latorre \& Rodríguez, 2007). In this study, it was determined that there was no topographic changes in the anatomical structures of the plastinated thoracic cavities and that the cross-sectional plastinated specimens were highly compatible with CT images. It has been reported in a previous study that dehydration, which is an important step of the plastination process, is usually carried out at $-25^{\circ} \mathrm{C}$, so that the displacement of the tissue fluids and acetone can be balanced and uniform so that the tissue shrinkage can remain at a minimum level (Brown $e t$ al., 2002). In present study, the dehydration phase was carried out with 3 consecutive acetone baths at $-25{ }^{\circ} \mathrm{C}$ to prevent excessive tissue shrinkage. It has been pointed out that in cold temperature silicone plastination, the S10 silicone polymer is mainly used with S3 catalyst material which activates this polymer (Sagoo \& Adds, 2013). In our study, it was expected to further protect the natural color of anatomical structures by using S10B pigmented silicone polymer which instead of S10 polymer.

A good interpretation of CT images leads to a more accurate diagnosis and an optimal treatment option for diseases as is known. CT images are usually formed in the transversal planes from the body region. However, it has been stated that, transversal images can be rearranged in sagittal or frontal planes by using certain software programs (Labruyere \& Schwarz). In this study, transversal CT images of the thoracic cavity were also evaluated in sagittal and frontal planes using 3D Slicer software. Thus, anatomical structures could be identified more easily and accurately. If the previous studies are reviewed, it can be noticed that CT imaging studies related to diagnosis of any disease of the thoracic cavities of cats (Henninger; Ohlerth \& Scharf; Rose et al.) as well as CT images of healthy anatomical structures and cross sectional cadaver images were evaluated together (Samii et al.; Shojaei et al.). The significant point that distinguishes our research from previous studies is the use of plastinated cross-sectional samples, unlike the use of frozen cadaver sections. Thus, the secondary aim for us was to use this specified plastinates for anatomy, radiology and also surgical trainings without deteriorating for many years.
It has been indicated that plastinated sections gave higher resolution than frozen cadaver sections, making it easier to compare them to CT images (Donoso et al., 2009). However, in our study, it was found that obtaining plastination sections was quite costly compared to preparation of frozen cadaver sections. CT and cross-sectional plastinated images of thoracic organs of dogs were compared in previous study (Polgar et al.). In that study, after the thoracic cavity of the dogs were separated into slices of $4 \mathrm{~mm}$ thickness, each slice was plastinated with Epoxy Resin Biodur E12 sheet plastination method. In our study, cold environment silicone plastination method was used and the compatibility of the cross-sectional plastinates with CT images was investigated. For our further studies, it is aimed to apply Epoxy Resin E12 sheet plastination technique to the thoracic organs of cats considering the related literature (Zöggeler et al., 2002; Polgar et al.; Ottone et al., 2016).

It has been reported that $3 \mathrm{D}$ anatomical models are very useful for students in anatomy trainings (Brazina et $a l$.). The benefits and advantages of using this kind of models in anatomy trainings have been revealed (Murgitroyd et al., 2015). It has been stated that 3D models, which are widely used in human medicine education, will be useful in veterinary medicine (Böttcher \& Maierl). It is thought that the anatomic $3 \mathrm{D}$ reconstructed models obtained in this study can be used effectively in veterinary surgery as well as veterinary anatomy trainings. It is possible to reconstruct 3D models using various softwares. 3D modeling mechanisms have been explained with various imaging softwares (Brazina et al.). 3D Slicer software used in our work can visualize directly from DICOM data with the facility of using discrete image using thresholding methods. In addition, this software can be downloaded without paying any fee, which greatly reduces the cost of research.

The data obtained in the study are thought to be beneficial in veterinary anatomy as well as veterinary surgery and radiology fields. It was also anticipated that this study can provide a modern approach to the field of anatomy, as well as shed light on the scientists who will research on the thoracic cavity of the cats.

ACKNOWLEDGMENTS. The Authors are deeply thankful to Prof. Dr. R. Merih HAZIROGLU (Head of Department of Veterinary Anatomy, Ankara University) and to Assoc. Prof. Dr. Selcuk TUNALI (Former Secretary of International Society for Plastination, TOBB ETU Hospital) for their precious contributions. We would also like to thank the technical assistant Ciydem COLAK (Department of Veterinary Surgery, Ankara University) for helping us during the imaging stage. 
AKGÜN, R. O.; BAKICI, C.; EKIM, O.; BUMIN, A. \& ÖNDER, O. I. Evaluación seccional de estructuras anatómicas de la cavidad torácica en gato (Felis catus) con imágenes de tomografía computada y métodos de plastinación de silicona. Int. J. Morphol., 36(4):1246-1251, 2018.

RESUMEN: El objetivo de este trabajo consistió en determinar las estructuras anatómicas en la cavidad torácica mediante tomografía computarizada (TC) y comparar las imágenes transversales en las mismas muestras, que fueron plastinadas después de la TC. También se pretendía obtener reconstrucciones tridimensionales (3D) de estructuras anatómicas torácicas. Se tomaron imágenes de los órganos torácicos de 3 gatos adultos por TC y luego se plastinaron en este estudio. Las muestras se plastinaron en la misma posición corporal en el proceso de obtención de imágenes TC. Las imágenes de TC y las secciones transversales plastinadas correspondientes se compararon entre sí. Las estructuras anatómicas de la cavidad torácica en los preparados plastinados estaban de acuerdo con las imágenes de CT. Además de las estructuras óseas, otros órganos como el esófago, la tráquea, el corazón con vasos relacionados, los pulmones y los músculos torácicos estaban bien definidos en las imágenes de TC y los plastinados. Por otra parte, se captaron bien las imágenes reconstruidas en 3D de las estructuras anatómicas de la cavidad torácica. Pensamos que este estudio es beneficioso para la cirugía veterinaria y los campos de radiología, así como también para la educación de anatomía veterinaria.

PALABRAS CLAVE: Gato; Tomografía computarizada; Plastinación; Silicona; Anatomía del tórax; Tridimensional.

\section{REFERENCES}

Böttcher, P. \& Maierl, J. Macroscopic cryosectioning: a simple new method for producing digital, three-dimensional databases in veterinary anatomy. Anat. Histol. Embryol., 28(2):97-102, 1999.

Brazina, D.; Fojtik, R. \& Rombova, Z. 3D visualization in teaching anatomy. Procedia Soc. Behav. Sci., 143:367-71, 2014.

Brenner, D. J. \& Hall, E. J. Computed tomography--an increasing source of radiation exposure. N. Engl. J. Med., 357(22):2277-84, 2007.

Brown, M. A.; Reed, R. B. \& Henry, R. W. Effects of dehydration mediums and temperature on total dehydration time and tissue shrinkage. J. Int. Soc. Plastination., 17:28-33, 2002.

Chang, C. W.; Atkinson, G.; Gandhi, N.; Farrell, M. L.; Labrash, S.; Smith, A. B.; Norton, N. S.; Matsui, T. \& Lozanoff, S. Cone beam computed tomography of plastinated hearts for instruction of radiological anatomy. Surg. Radiol. Anat., 38(7):843-53, 2016.

DeJong, K. \& Henry, R. W. Silicone plastination of biological tissue: Coldtemperature technique BiodurTM S10/S15 technique and products. $J$. Int. Soc. Plastination., 22:2-14, 2007.

Donoso, S.; Sora, M. C.; Probst, A.; Budras, K. D. \& König, H. E. Mesoscopic structures of the equine toe demonstrated by using thin slice plastination (E12). Wien Tierärztl. Mschr., 96(11):286-91, 2009.

Estai, M. \& Bunt, S. Best teaching practices in anatomy education: A critical review. Ann. Anat., 208:151-7, 2016.

Henninger, W. Use of computed tomography in the diseased feline thorax. J. Small Anim. Pract., 44(2):56-64, 2003.
Kim, M.; Huh, K. H.; Yi, W. J.; Heo, M. S.; Lee, S. S. \& Choi, S. C. Evaluation of accuracy of 3D reconstruction images using multi-detector CT and cone-beam CT. Imaging Sci. Dent., 42(1):25-33, 2012.

Kumro, S. L.; Crocker, A. V. \& Powell, R. L. Injection plastination: A lowtech, inexpensive method for silicone preservation of small vertebrates. J. Int. Soc. Plastination, 25(1):12-7, 2013.

Labruyere, J. \& Schwarz, T. CT and MRI in veterinary patients: an update on recent advances. In Practice, 35:546-63, 2013.

Latorre, R. \& Rodríguez, M. J. In search of clinical truths: equine and comparative studies of anatomy. Equine Vet. J., 39(3):263-8, 2007.

Murgitroyd, E.; Madurska, M.; Gonzalez, J. \& Watson, A. 3D digital anatomy modelling - Practical or pretty? Surgeon, 13(3):177-80, 2015.

Ohlerth, S. \& Scharf, G. Computed tomography in small animals--basic principles and state of the art applications. Vet. J., 173(2):254-71, 2007.

Ottone, N. E.; del Sol, M. \& Fuentes, R. Report on a sheet plastination technique using commercial epoxy resin. Int. J. Morphol., 34(3):103943, 2016.

Özkadif, S. Some veterinary anatomic studies fulfilled using three dimensional reconstruction. Batman Univ. J. Life Sci., 5(2):288-95, 2015.

Polgar, M.; Probst, A.; Sora, M. C. \& König, M. C. Plastinierte körperfeinschnitte als neues hilfsmittel zur darstellung der schnittanatomie am beispiel der brusthöhle des hundes. Wien Tierärztl. Mschr., 90:45-52, 2003.

Riederer, B. M. Plastination and its importance in teaching anatomy. Critical points for long-term preservation of human tissue. J. Anat., 224(3):30915, 2014.

Rose, A. M.; Ryan, S. D.; Johnstone, T. \& Beck, C. Imagıng diagnosis-The computed tomography features of a pleuroperitoneal hernia in a cat. Vet. Radiol. Ultrasound., 58(5):E55-9, 2017.

Sagoo, M. G. \& Adds, P. J. Low-tem- perature dehydration and roomtemperature impregnation of brain slices using BiodurTM S10/S3. J. Plastination, 25(1):3-8, 2013.

Samii, V. F.; Biller, D. S. \& Koblik, P. D. Normal cross-sectional anatomy of the feline thorax and abdomen: comparison of computed tomography and cadaver anatomy. Vet. Radiol. Ultrasound., 39(6):504-11, 1998.

Shojaei, B.; Rostami, A.; Vajhi, A. \& Shafaee, M. Computed tomographic anatomy of the thoracic region of the cat. Vet. Arch., 73(5):261-9, 2003.

von Hagens, G.; Tiedemann, K. \& Kriz, W. The current potential of plastination. Anat. Embryol. (Berl.), 175(4):411-21, 1987.

Zöggeler, E.; Probst, A.; Sora, M. C. \& König, H. E. Plastinierte Körperfeinschnitte als neues Hilfsmittel zur Darstellung der Schnittanatomie am Beispiel der Bauch- und Beckenhöhle des Hundes. Wien Tierärztl. Mschr., 89:115-21, 2002.

Corresponding author:

Remzi Orkun Akgün

Ankara University

Faculty of Veterinary Medicine

Department of Anatomy

06110, Ankara

TURKEY

Email: akgunorkun@hotmail.com

Received: 18-05-2018

Accepted: 17-07-2018 